DOI https://doi.org/10.18551/rjoas.2017-10.39

\title{
THE EFFICIENCY OF USE OF INNOVATIVE TECHNOLOGIES FOR GRINDING THE GRAIN CROPS
}

\author{
Alekseev G.V., Doctor of Technical Sciences \\ Saint Petersburg State National Research University of Information Technologies, \\ Mechanics and Optics, Saint Petersburg, Russia \\ Romanchikov S.A., Candidate of Technical Sciences \\ Military Academy of Logistics, Saint Petersburg, Russia \\ Leu A.G., Magister \\ Saint Petersburg State National Research University of Information Technologies, \\ Mechanics and Optics, Saint Petersburg, Russia \\ Derkanosova A.A.*, Candidate of Technical Sciences \\ Voronezh State University of Engineering Technologies, Voronezh, Russia \\ *E-mail: aa-derk@yandex.ru
}

\begin{abstract}
The experience of advanced industries shows that at the current stage of the development of technologies, the effectiveness of investments in improving funds based on innovative developments is higher than investment in the new equipment. The high rates of obtaining new knowledges about the processes make it possible to ensure a high level of improvements and, thereby, to make the potentialities of innovative technical solutions more fully use. At the same time, the main sources of economic efficiency of innovation-based technological processes are: reducing the costs of energy resources, the cost of production and the loss of raw materials. The modern domestic flour milling industry belongs to the number of socially important branches of the national economy, since the products produced from flour are vital for all categories of the population. Because the flour production is resource intensive, and the quality and the cost of grain and products play a decisive role in its competitiveness, the introduction of innovative technologies in the production processes is becoming one of the main sources of growing the efficiency of a flour mill as a whole.
\end{abstract}

\section{KEY WORDS}

Efficiency, grinding, parameters, construction, working camera, simulation.

Among the main problems of grinding and mixing of dispersed environments with the participation of the solid phase depending on the settled goals, during the processing of the grain crops, the following are included: creation of food products with new properties; giving new flavors to the known products; giving an attractive look, the desired color scheme; increasing the shelf life of food products.

Solving these problems, the main problem of grinding and mixing is to obtain the maximum amount of the mixture in the shortest possible time with minimal costs of energy. In this connection, it is advisable to introduce the efficiency parameter as the ratio of the usefully achieved technological result of grinding $(\Delta S)$ to the total energy costs achieved per unit of working bulk of the working space:

$$
\ni=\frac{\Delta S}{V_{A} \cdot N}
$$


After some transformations, we can reduce this relationship the form:

$$
\ni=\frac{\Delta S \cdot \Pi_{P S}}{V_{A} \cdot N}
$$

Approximation of the dependence of the parameter of the energy efficiency $\ni$ on the productivity of the mill or crusher on the finished product $V_{M}$ is carried out using Excel spreadsheets. The dependence is approximated by a power function of the form:

$$
\ni=n V_{\mu}^{-1}
$$

Where: $n$ - numerical coefficient (varies from 1200, for the upper limit of points to 1 - the lower limit).

The volumetric capacity of the mill or crusher for the finished product is in the numerator, so it is logical to expect the direct proportionality of $\ni$ and $V_{M}$, but the effect of the remaining parameters, in turn, is a function of productivity, leads to an inversely proportional relationship.

The analysis carried out with the help of the proposed parameter shows that among the most effective shredders are jet shredders, especially for high productivity.

Let's consider the realization of the jet milling process with the help of an aggregate in the simplest case, which contains drainage cylindrical branch pipes, crimping segments with some holes combined with the holes of the cylindrical branch pipes, and elastic gaskets having holes combined with the holes of the crimp segments. They are made with the possibility of joint movement along the external surface of the body of the working chamber at the outlet holes points, simultaneously up or down from the horizontal axis of the chamber shown on Figure 1.

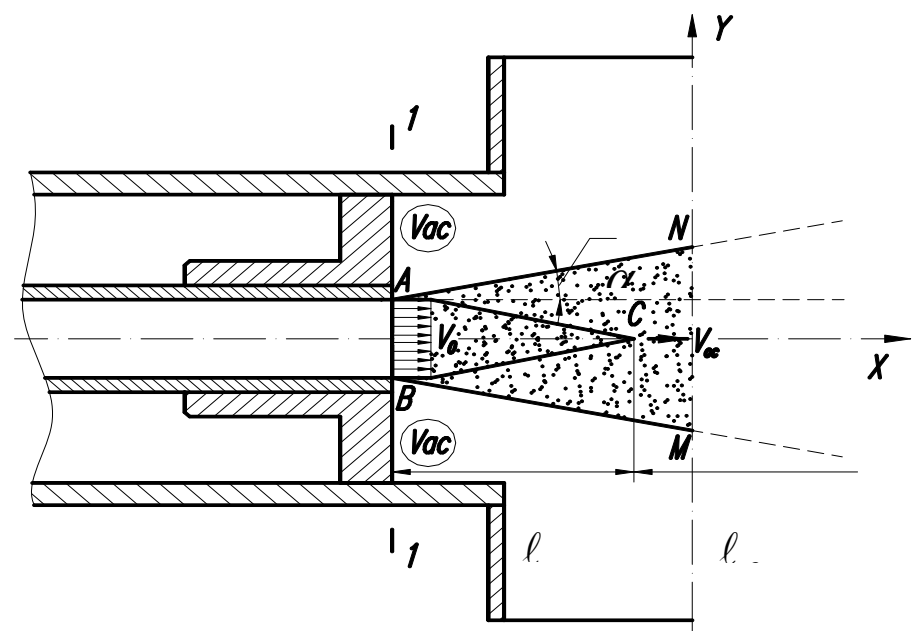

Figure 1 - Distribution of grain in the chamber of the jet shredder

When the drainage cylindrical branch pipes, crimping segments and elastic gaskets are moved together, simultaneously up or down from the horizontal axis of the chamber, the angle of rotation $\varphi$ formed by the axis of the working chamber and the axis of the branch cylinder pipe changes the angle of withdrawal of the finished product from the grinding zone $\alpha_{\Pi}$ - formed by the vertical axis working chamber and the axis of the drainage cylindrical branch pipe.

Let the gas carrier obeys the laws of motion of a submerged jet and has a drop-like form. This assumption is completely correct, since the jet coming out of the accelerating tube does not immediately fill the entire cross section of the working chamber. 
It breaks away from the walls and then moves in the form of a free jet separated from the rest of the environment by the interface. The interface is usually unstable; vortices appear on it and as a result the jet mixed with the surrounding environment. When the flow of a jet out of the accelerating tube, in its output section $1-1, v_{0}$ is equal to each other at all points of the section. Over the length of the initial section, the axial velocity is constant in magnitude and equal to the velocity at the incision of the accelerating tube $v_{0}$.

In the area of an isosceles pressure triangle, the base of which coincides with the plane of the incision of the accelerating tube at all points of the jet, the velocities of the gas carrier are equal to each other and are also equal to $v_{0}$ - this area forms the so-called core of the jet.

In the annular space between the jet and the walls of the working chamber, the environment is in a vortex motion. It is gradually drawn into the central jet from this zone, and on the other hand, the environment from the central jet enters the vortex zone. The energy of the energy carrier dissipates, owing to its detachment from the accelerating tubes, while the energy along the axis is dissipated at a greater length than at the periphery.

In the connection with the small distance from the incision of the accelerating tubes to the plane of impact of the flying jets, causes the area of the jet with a rectilinear generator, for which, according to AA. Goleevsky, the coefficient of energy dissipation of a flooded jet is equal to $\varphi=0 \div 0,67$.

As the motion along the axis of the jet is blurred, and half of the angle of expansion can be determined by the term:

$$
\operatorname{tg} \alpha^{\prime} \approx k \cdot\left(1+\psi \cdot \frac{V_{1}}{V_{0}}\right) \cdot \operatorname{tg} \alpha
$$

Where:

- $V_{0}$ - the speed of the energy carrier at the incision of the accelerating tube, $\mathrm{m} / \mathrm{s}$;

- $V_{1}$ - the velocity of entrained environment, $\mathrm{m} / \mathrm{s}$;

- $k$-coefficient of the shape of the accelerating tube;

- $\psi$-coefficient that depends on the velocity of the entrained environment;

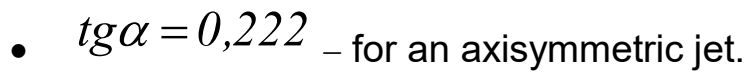

Let's take into account that the initial sections of the jet are unchanged in the length and the angle of expansion. In this case, the length of the initial segment can be calculated by the formula proposed by G.N. Abramovich [3]:

$$
\ell_{H}=0,335 \cdot \frac{d_{m p}}{a}
$$

Where: $d_{m p}$ - diameter of the accelerating tube, $\mathrm{m} ; \mathrm{a}$ - turbulence coefficient, $a=0.07 \div 0.08$.

In this case the length of the flooded jet can be determined:

$$
\ell=\frac{\varphi}{1-\varphi} \cdot \frac{d_{m p}}{2 \cdot \operatorname{tg} \alpha^{\prime}}
$$

If we assume that the stable part of the jet develops independently of the degree of constraint and the content of the solid phase in it, then the expressions described above describing single-phase jets can also be used to calculate two-phase jets.

Getting into the jet of energy carrier during the process of injecting, solid particles are accelerated by the flow. Moving in the stream over the accelerating tube corpuscles of the 
material to be minced acquire at the entrance to the working chamber a velocity $U$, which is lower than the velocity of the energy carrier $V_{0}$. After leaving the accelerating tubes, when the jet passes into the working chamber, due to the loss of the stability, the velocity of the carrier gas falling.

In this case, the solid phase is released from the jet, and the material corpuscles due to their inertia retain the velocity $U$. Thus, after some distance from the incision of the accelerating tube, a moment comes when the velocity of the corpuscles $U$ becomes equal to, and then also of the higher velocity of the energy carrier $V_{0}$, the energy from the solid phase begins to shift to the gas phase, which leads to the deceleration of the corpuscles.

To prevent undesirable for the grinding efficiency of the corpuscles of the ground material, the distance between the cut of the accelerating tube and the middle plane in the working chamber is selected for reasons of maintaining the maximum velocity of the material corpuscles.

Some known methods for calculating countercurrent jet devices [2], the distance between the incision of the accelerating tube and the middle plane it is recommended to be chosen equal to half the length of the potential jet nucleus:

$$
\ell_{c m p}=2,22 \cdot d_{m p}
$$

As this distance increases, the area of encounter of potential jet nuclei and the efficiency of grinding decrease. With a decrease of in the counter pressure on the sections of the accelerating tubes of the ejectors increases, this also worsens the grinding characteristics of the machine.

In the framework of the study experiments of studying the influence of the distance between the cut of the accelerating tube and the middle plane in the working chamber on the counter pressure at the exiting section of the accelerating tubes were conducted.

The studies were carried out directly in the laboratory installation with the absolute air pressure changing before the ejector $P_{8 x}=0,4 \div 0,6 \mathrm{MPa}$, which corresponds to the working conditions of the jet mill equipped with a working chamber with an adjustable angle of the finished product withdrawal from the grinding zone.

A measurement of the static pressure at the exit from the accelerating tube, according to which the influence on the back pressure was evaluated, was taken from the liquid Ushaped manometer. The results of the experiment are presented in the form of a table.

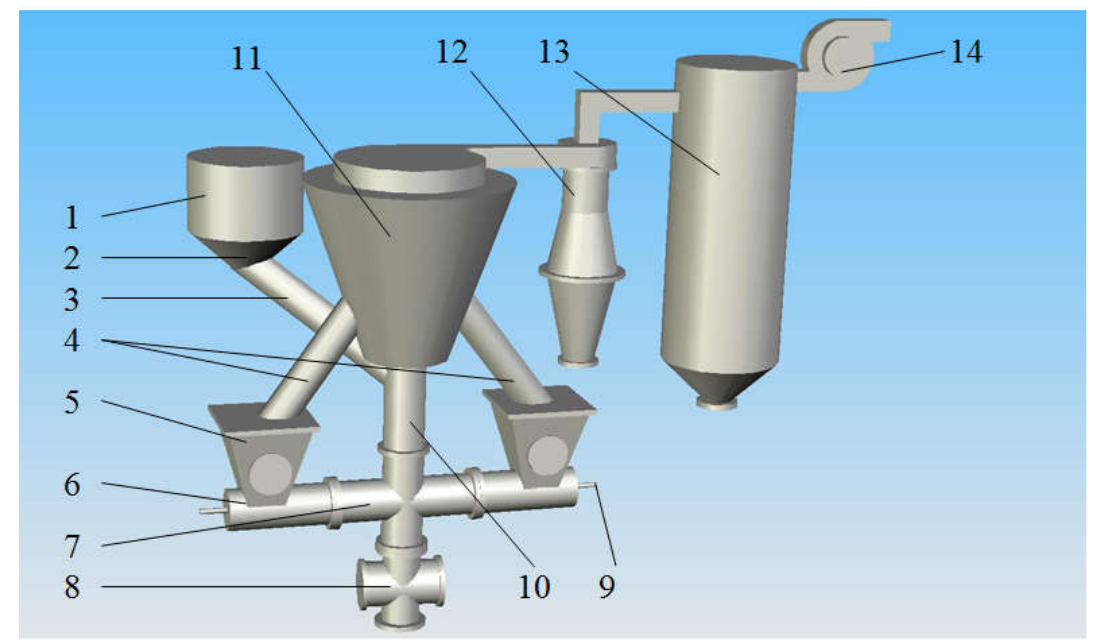

Figure 2 - Schematic diagram of the jet disperser: 1 - bunker for grain; 2 - the feeder; 3 - a pipe of giving of a material in a disperser; 4 - return tubes; 5 - material receiver; 6 - grinding ejector; 7 - grinding chamber; 8 - source of electromagnetic field; 9 - the main power line; 10 - dust pipe nozzle; 11 - separator; 12 - cyclone; 13 - bag filters; 14 - exhaust fan. 
Table 1 - The dependence of the pressure at the exit from the accelerating tube on the distance between the cut of the accelerating tube and the plane of symmetry of the working chamber

\begin{tabular}{|c|c|c|c|c|c|c|c|}
\hline \multirow{2}{*}{$\begin{array}{c}\text { Variable } \\
Y_{i}\end{array}$} & \multicolumn{7}{|c|}{$\begin{array}{l}\text { The distance between the incision of the accelerating tube and the plane of symmetry } \\
\text { in the working chamber } \ell_{c m p}\end{array}$} \\
\hline & $0,5 \cdot d_{m p}$ & $d_{m p}$ & $1,5 \cdot d_{m p}$ & $2 \cdot d_{m p}$ & $2,5 \cdot d_{m p}$ & $3 \cdot d_{m p}$ & $3,5 \cdot d_{m p}$ \\
\hline 0,4 & 686,5 & $-343,2$ & $-196,1$ & $-137,3$ & $-68,6$ & $-68,6$ & $-68,6$ \\
\hline 0,5 & - & 1176,8 & $-343,2$ & $-245,2$ & $-127,5$ & $-78,5$ & $-78,5$ \\
\hline 0,6 & - & - & 1569,1 & $-735,5$ & $-441,3$ & $-147,1$ & $-117,7$ \\
\hline
\end{tabular}

During the analysis of the data from Table 1, it is necessary, first of all, to pay attention to the tendency of its change, depending on the reduction in the distance between the cut of the accelerating tube and the middle plane, but not on the absolute values of the static pressure. Statistical processing of data using the Mathcad software package is shown in Figure 4.

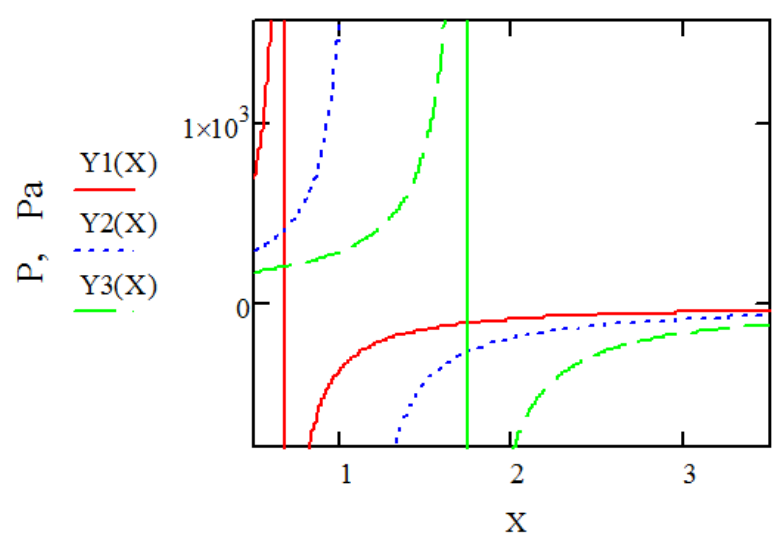

$L, 1(0.5-3.5) \mathrm{d}$

Figure 3 - Static pressure at the exit of the accelerating tube

Based on the analysis of the test results, it can be concluded that the distance between the cut of the accelerating tube and the middle plane in the grinding chamber does influence on the effective operation of the ejectors. It has been experimentally established that for a camera with variable parameters with minimum energy expenditure it is expedient to choose it from the condition:

$$
\ell_{c m p}=1,5 \div 2 \cdot d_{m p}
$$

\section{REFERENCES}

1. Gerasimenko V.B., Kucherova E.A., Dudukalo A.YU. Pomol syr'ya i dobavok dlya proizvodstva elektroizolyacionnoj keramiki. V sbornike: Energosberegayushchie tekhnologicheskie kompleksy i oborudovanie dlya proizvodstva stroitel'nyh materialov Mezhvuzovskij sbornik statej. Pod red. V.S. Bogdanova. Belgorod, 2014. S. 117-121.

2. Semikopenko I.A., YArcev D.I. Napravlenie razvitiya strujnyh izmel'chitelej. V sbornike: Energosberegayushchie tekhnologicheskie kompleksy i oborudovanie dlya proizvodstva stroitel'nyh materialov Mezhvuzovskij sbornik statej. Belgorod, 2014. S. 122-125.

3. Patent RF na poleznuyu model' №170192. Strujnyj dispergator pishchevyh dobavok / Alekseev G.V., Pal'chikov A.N., Karpachev D.V., Zolotareva A.A.; Universitet ITMO; №2016144539; №11.

4. Karpachyov, D.V., Galicyn, A.E. Kulyakina, O.V. Strujnyj dispergator dlya tonkogo izmel'cheniya yaichnoj skorlupy [Elektronnyj resurs] / D.V. Karpachyov, A.E. Galicyn, 
O.V. Kulyakina // Naukoemkie tekhnologii i innovacii: Mezhdunar. nauch.-prakt. konf. Belgorod, 2016. Vol. 4. - S. 73-77.

5. Alekseev, G.V., Aksenova, O.I., Karpachev, D.V. Osobennosti podgotovki kal'cijsoderzhashchih pishchevyh dobavok dlya ispol'zovaniya // Vzaimodejstvie nauki i obshchestva: problemy i perspektivy: Sb. st. Mezhdunar. nauch.-prakt. konf. - Ufa: 2015. - S. 28-30.

6. Tutel'yan V.A., Pogozheva A.V.. Rol' pishchevyh volokon $v$ pitanii cheloveka.Rol' pishchevyh volokon $v$ pitanii cheloveka/Pod red. V.G. Vysockogo. - M.: Novoe tysyacheletie, 2008. $-320 \mathrm{~s}$.

7. Makkans R., Uiddouson E.H. Himicheskij sostav i energeticheskaya cennost' pishchevyh produktov. M.: $2006.420 \mathrm{~s}$.

8. Volkov K., Emel'yanov V., Zazimko V. Turbulentnye strui - statisticheskie modeli i modelirovanie krupnyh vihrej. SPb, 2013, $360 \mathrm{~s}$.

9. Alekseev G.V., Kondratov A.V. Perspektivy primeneniya kavitacionnogo vozdejstviya dlya izmel'cheniya pishchevyh produktov. Monografiya / Saratov, 2013.

10. Lozovaya S.Y., Bocharova Y.L. Centrobezhnyj gomogenizator dlya mekhanicheskoj obrabotki pishchevyh produktov. V sbornike: Energosberegayushchie tekhnologicheskie kompleksy i oborudovanie dlya proizvodstva stroitel'nyh materialov Mezhvuzovskij sbornik statej. Belgorod, 2014. S. 130-132.

11. Shevtsov A.A. Modeling the process of grain drying in a straight-through silo grain dryer / Shevtsov AA, Pavlov IO, Drannikov AV, Evdokimov AV // Vestnik VGUIT [Proceedings of VSUET]. 2005. № 10. S. 136-143.

12. Shevtsov A.A. Topological principle of formalization of the system of drying and storage of grain by methods of mathematical modeling / Shevtsov AA, Pavlov I.O., Fursova E.V. // Vestnik VGUIT [Proceedings of VSUET]. 2006. № 11. S. 45-50. 